\title{
Technology as a Source of Language Input and Practice and its Influence on the Vocabulary Development of University EFL Students
}

\author{
https://doi.org/10.3991/ijes.v9i4.24715 \\ Adela Talbi Hassani ${ }^{(凶)}$ \\ University of Algiers 2, Algiers, Algeria \\ adelaia@yahoo.fr
}

\begin{abstract}
This paper addresses the extent to which technology-based language resources influence the vocabulary development among University students learning English as a foreign language (EFL), in terms of the growth of the receptive vocabulary size as well as the use of vocabulary learning strategies (VLS) across the three years of the undergraduate course. Findings reveal that the highly frequent use of multimedia tools was largely confirmed; however, for most students there was no significant correlation between the use of such resources and the growth pattern of their vocabulary knowledge. Only the low-intermediate students were the exception as their use of Internet to search for information or to communicate with others seemed to be significantly correlated to their vocabulary development. These findings have interesting implications as they show the high potential of technology-based resources in developing vocabulary especially in totally digital-free environments in which English is taught as a foreign language (FL), and used only in classroom contexts. Learners appear to be avid of technology- based tools, but they seem to need assistance from instructors to maximize this positive support.
\end{abstract}

Keywords - technology, vocabulary learning, multimedia, English language

\section{Introduction}

Teaching vocabulary at university level is quite challenging, especially in an EFL environment like Algeria in which exposure to the target language is usually restricted to the classroom. The fact that the number of students in the classroom is usually quite large may lead to limited participation and language practice. Besides, the restricted time spent in class makes it impossible for the teacher to teach all the vocabulary the students need. One of the tools which can be used to provide more exposure to the target language (TL), better opportunities to practice it, as well as varied sources for vocabulary learning is the use of multimedia. Indeed, technology-based resources can support learners' autonomy in language learning in general by giving them the possibility to take control of their own learning and use their strategic competence. Such resources are believed to activate learners' cognitive and metacognitive awareness [1]. 
These latter which consist of the ability to manipulate the TL in a away that transforms it and makes it easy to retain, as well as the conscious analysis of the learning scene and decision-making about what needs to be done [2], are crucial elements to develop for any university students aiming to be autonomous.

When one thinks of communication in language learning, the 'classical' context is usually a face-to-face setting during which individuals exchange in many ways. However, the emergence and democratization of internet and various electronic tools have led to new forms of communication, and English has become the most predominant language used on the internet [3]. Learners studying English can therefore have access to limitless resources by means of technology, such as television, computers, smartphones, etc.

\section{Technology in language learning}

One of the prominent researchers who advocated the importance of integrating multimedia resources into language teaching is Mayer who suggested the Multimedia Learning Theory [1]. According to him, using images, sounds and words makes language learning more effective as they allow the learner to be strategically involved in his learning process and develop mental representations of the input. Integrating the auditory, textual and visual information, making mental connections between them, as well as relating them to prior knowledge are all mental processes that involve the active multi-sensory engagement of the learner, and this is believed to trigger construction of new language knowledge, including vocabulary. Thus, the self-directed and strategic learning that is achieved through technology-related resources can lead learners to become agents in their own language learning process by controlling different features of their learning to meet their objectives, managing aspects such as their emotions and cognition, as well as choosing and using the appropriate learning strategies that match various tasks [4]. Such awareness-raising is valuable when one knows that progress in vocabulary learning is highly related to the extent to which a learner has metacognitive awareness of his own needs and learning strategies use, and is therefore able to structure his learning adequately and make use of various vocabulary strategies to meet his learning objectives [5] [6].

One of the benefits of multimedia and internet resources is the amount of visual and auditory materials that learners can very easily have access to, most of which are free of charge. These materials provide them with real-life and authentic input that can motivate them to learn language directly or indirectly. The materials available through technological tools can be in the form of texts, graphics, images, audios, videos, and applications. In terms of using multimedia in language teaching, the use of visuals and sensory-aids plays an important role in making strategy instruction in the classroom more effective and realistic [7]. This is particularly relevant in EFL environments in which the only source of input is the teacher, thus the use of multimedia-related resources can be an alternative technique to incorporate visuals and sensory effects into vocabulary learning strategy instruction and improve vocabulary learning in general. For instance, some studies have demonstrated that the use of multimedia resources to integrate pictures and word definitions maximize vocabulary retention among 
learners [8]. In his study undertaken with 94 college-level students learning Spanish as a FL, Yangas [8] investigated the possible effect of multimedia glosses on written text comprehension as well as on vocabulary learning. While reading a written text online, three types of multimedia words glosses were used, namely textual, pictorial and a combination of both, in parallel a control group was given the written text without any glossing, i.e., without explanation of the underlined words. Results showed that the groups who had access to the different types of multimedia glosses were able to recognize the targeted words much more significantly than the control group who was given the text to read directly. Thus, whether textual, pictorial or a combination of both, the glosses provided by technology seemed to play an important role in the cognitive processing of the students to achieve text comprehension.

Besides the early 2000's technology-based resources that can be used to enhance vocabulary learning, such as CDs, internet websites and platforms, social media have been considered recently to play a more significant role in the development of vocabulary knowledge in various EFL/ESL environments [9] [25] [26] [27]. Indeed, these tools allow the learners not only to get input and information about different aspects of the TL, but they most importantly enable them to interact with other native or non-native speakers of the TL, and therefore to develop their communicative competence in and outside the classroom.

In the Algerian society, the use of social media has become a major source of information and news, especially among young people in large cities, and a means of expression and empowerment. In recent years, the popularity of social media platforms such as Facebook, Twitter, Instagram, YouTube, Tiktok, WhatsApp, etc. has enabled people of different ages to interact and share contents in various aspects of life, through computers or smart phones. As far as language learning is concerned, the emergence of social media in the last couple of decades has started to attract interest as some studies worldwide have investigated the effect of such resources on language learning in general and vocabulary acquisition in particular [10] [11] [12] [13] [14]. All these studies undertaken among university level students learning English as a FL have demonstrated that the adequate use of tools such as Twitter or Facebook makes a significant difference in terms of gaining larger vocabulary knowledge, especially when compared with control groups for whom more traditional multimedia-free teaching was applied. The use of these multimedia resources was found to lead to students' significant improvement in vocabulary comprehension and retention. The authentic and attractive input provided by visual aids like online videos is seen as highly motivating and enjoyable; this type of input boosts learners' involvement and engagement in the learning process and allows them to learn more strategically.

Most of the studies mentioned above advocate the need to integrate different types of multimedia or technology-based resources in and outside the EFL classroom as such tools can be complementary to traditional classroom teaching and can help students to develop better vocabulary knowledge and more autonomous and strategic learning. Indeed, when the learner is involved in his own learning process, the more autonomous he is, the more appropriate choices he makes in terms of learning strategies to achieve better vocabulary acquisition. However, the use of digital technology in general and social media in particular should be monitored in order to minimise the negative effects of these devices and maximize their benefits. For instance, it is usually agreed that most 
students tend to be quite dependent on social media and can therefore easily lose track of their advantages and develop inadequate linguistic codes that can become fossilized and difficult to readjust. Offering guidance to students on how to best use other input resources such as multimedia would in a way promote learning how to learn.

\section{Importance of vocabulary development}

Words are the key elements to people wanting to express their thoughts, gain knowledge, or learn new concepts in any field. This is particularly true in the educational scene, as the academic success of students is usually closely related to their vocabulary knowledge and use in their field of study. At university, vocabulary knowledge can determine the extent to which students are able to understand what they read or what they hear, as reading textbooks and listening to lectures are usually the major sources of input for university students, especially in a foreign language environment.

Among the various components of a language, vocabulary is probably the most dynamic and changing. Indeed, while other aspects such as grammar, syntax, phonology are quite stable and rarely influenced by external factors, words of any given language are in continuous movement since new words are constantly added to dictionaries as a reflection of the evolution of humans and changes in society and the world in general.

Vocabulary is crucial for EFL learning, and one way of explaining this importance is through the analysis of the learners' needs as the role that vocabulary-or any other aspect of the target language-plays in the learning process is closely related to what learners need this language for. For instance, an EFL student enrolled in an English language university degree course would need to become competent in all components of the language, including vocabulary, to be able to embrace an English language related career like teaching. One would expect him to understand any type of input in the target language while listening and reading, and to communicate correctly and comprehensibly when speaking or writing. Considering these four language skills, the vocabulary that an EFL student needs to know would certainly have an impact on the way he would use the receptive and productive language skills to read a novel, understand a lecture, make a presentation, write an assignment or a report, answer exam questions, etc. The large amount of vocabulary knowledge that this learner needs in order to operate efficiently in the target language can by no means be taught by the teacher given the limited time spent in class and the lack of exposure to the language outside the classroom environment. To cope with this restricted amount of lexical input, EFL learners need to take responsibility of much of their vocabulary learning through the use of learning strategies. The adequate use of strategies is particularly important given the fact that vocabulary is an element of language that constantly evolves and expends. The strategies that the learner might make use of outside the classroom, i.e., without the teacher's help, are considered by Nation [15] to be the most crucial in the vocabulary learning process, and the use of technology based sources of language can be one of the strategies used for that purpose. Identifying the strategies that learners use to expand their vocabulary knowledge is therefore a highly important element that allows a better understanding of the process through which learners acquire the TL in general and the vocabulary component in particular [6]. 


\section{$4 \quad$ Research methodology}

The English degree course at the University of Algiers 2 is taught through the LMD curriculum (Licence-Master-Doctorate). Across the three years of the undergraduate stage, the vocabulary component is not directly taught but it is rather integrated within various language courses (Reading, Writing, Speaking, Listening). Despite the fact that these courses cover the vocabulary element of the target language in its different forms and give the students an overview of the language learning strategies they can make use of to maximize their learning, there is no specific strategy training within the curriculum that teaches students ways to cope for insufficient vocabulary knowledge through autonomous lexical learning.

Knowing that students enrolled in the undergraduate course are young adults who are certainly quite "connected" to technological devices and internet, and acknowledging the potential that technology offers in terms of complementary resources to use in or outside the classroom, the purpose of the present study was to investigate the extent to which students' use of technology in their language learning concretely influences the development of their vocabulary knowledge in terms of vocabulary size as well as Vocabulary learning strategies (VLS) use across the three years of the undergraduate course.

The present paper focuses on only one aspect extracted from the overall $\mathrm{PhD}$ work of the author.

\subsection{Participants}

The overall number of the population was 184 students enrolled in the English undergraduate course. There were four sample groups each representing a proficiency level as follows:

Newly enrolled students (low-intermediate)

Year 1 students (pre-intermediate)

Year 2 students (intermediate)

Year 3 students (advanced)

The purpose of involving students across the different stages of the undergraduate course was to study the growth pattern of vocabulary development and technology influence from the time the students join the university until their graduation. It was also interesting to check whether there was any change/evolution in the influence of one construct over the other when students move to upper language proficiency levels.

\subsection{Procedure}

In order to analyse the possible impact of technology related devices and resources on the vocabulary growth pattern of the students, each construct was researched individually before possible correlations could be set up.

As such, the vocabulary size was researched by means of Nation's [16] Vocabulary Size Test (VST). This well-known standardized test aimed at measuring the written 
receptive vocabulary knowledge and comparison between the results of the four sample groups would allow analysis of the growth of this vocabulary size from one proficiency level to the other. The test had a multiple-choice format and the participants had to select the appropriate definition of given words by simply ticking the right answer.

The second construct of Vocabulary Learning Strategies (VLS) was researched by means of Schmitt's [2] VLS questionnaire in which the participants were asked about the strategies they use when they do not know or understand a word, as well as the strategies they prefer to reinforce the word and retain it after discovering its meaning. In other words, they were requested to select, from a pre-established list of strategies, the ones they used and their frequency of use.

As far as the place of technology and multimedia in the language learning process was concerned, an open-ended questionnaire was designed by the researcher to gather information about the participants' overall exposure to English outside the classroom, in a foreign language environment like Algeria where English is rarely used outside educational institutions. The subjects were thus questioned about their access and use of English speaking media such as television channels, and the availability of internet in their immediate environments outside the classroom. Moreover, the participants were also asked to mention any other vocabulary learning strategies that they could think of and that were not included in Schmitt's VLS test mentioned above.

After analysing each construct individually, the correlation between the overall vocabulary development and the use of technology-based resources was studied across the three years of the undergraduate course, as this was the major focus of the present paper.

\subsection{Results and discussion}

Analysis of results demonstrated that there was a moderate growth in the number of vocabulary words the students know as they move to upper proficiency levels. In fact, from the time they joined the undergraduate course and across the three years of study, the average vocabulary size moved from knowledge of 5924 word families to 7500. However, in terms of the use of vocabulary strategies, the participants' behaviour seemed to be significantly identical. Indeed, when analyzing the use of various strategies and establishing a top-10 classification of the most frequently used ones, the four sample groups demonstrated the same preferences, reflecting a very limited evolution in terms of VLS choice. For a majority of participants, the most frequently used strategies were metacognitive categories, ie, the ones related to conscious or unconscious analysis of the learning scene and decision-making about what needs to be done by the learner [2]. This category includes strategies such as the use of English speaking media (songs, movies, newscasts, etc.), internet, or other technology-based tools for the sake of learning.

Social strategies, on the other hand, were the least frequently used; these comprise the use of social aids to discover meaning of new words by cooperating and asking assistance from someone else such as the teacher or classmates. When establishing a top-10 of the most frequently used strategies among the whole population, a majority of strategies where related to the use of technology-based tools such as English language 
$\mathrm{TV}$, as well as internet to search for information or to communicate with others using English language. Given that the average age range of the participants was around 20, the use of these metacognitive strategies confirms the general assumption that young adults heavily rely on multimedia tools to improve and reinforce their learning.

One has to mention that the neglect of social strategies in EFL contexts is thought to be due to the lack of collaborative learning habits and interaction with native speakers, teachers or classmates as a source of vocabulary development compared to ESL (English as a Second Language) contexts [2]. In such contexts, the potential benefits of using internet and other technology as sources of input and exchanges would certainly provide the interaction that is generally limited.

When asked about the degree of access to English speaking media, most participants indicated that they watch English speaking TV channels regularly and have a significantly high access to internet outside the classroom. As shown in Table 1, over $76 \%$ of the participants declared watching English speaking TV channels such as:

- US channels: MTV, CNN, Fox, National Geographic

- British Channels: BBC, Eurosport

- Middle eastern channels: MBC, Dubai 1, El Djazeera

Moreover, between $66 \%$ and $81 \%$ stated that they have internet at home, while the others get access from cybercafés. Thus, most of the participants could easily use internet as a supporting tool for their English language learning in general, and possibly their vocabulary learning as well.

Table 1. Participants' access to internet and English speaking media

\begin{tabular}{|l|c|c|c|}
\hline \multicolumn{1}{|c|}{ Participants } & Internet at Home & Internet Outside & Access to English TV \\
\hline Newly enrolled & $80 \%$ & $6 \%$ & $76 \%$ \\
\hline 1st Year & $81 \%$ & $9 \%$ & $88 \%$ \\
\hline 2nd Year & $78 \%$ & $16 \%$ & $86 \%$ \\
\hline 3rd Year & $66 \%$ & $27 \%$ & $86 \%$ \\
\hline
\end{tabular}

In the open-ended questionnaire, the participants were given the possibility to add any vocabulary-related strategy they could think about and that was not mentioned in Schmitt's list. The purpose was to find out whether there were any other techniques that the participants used to improve their understanding and retention of vocabulary items and therefore to increase their vocabulary size. Moreover, the aim was to check whether their added suggestions concord with the preferred strategies they reported to use in the VLS questionnaire. Their various answers were categorized by the researcher to fit into Schmitt's categorization of VLS, and are shown on Table 2.

The determination strategies mentioned by the participants mostly related to the discovery of unknown words' meaning through the use of translation as a technique to guess the meaning of words. However, unlike in Schmitt's taxonomy, this technique reported by the participants was heavily related to technological devices such as the cell phone, internet, or multimedia supports. Given that most cell phones used by young adults are smart phones with installed dictionaries applications, the participants 
reported using these dictionaries quite often. The use of other multimedia devices was also reflected in the example of the use of Google as a research engine to look for meaning of new words. Moreover, some participants reported searching the meaning of words they heard in movies, videos or e-books. Participants also mentioned making word lists and recording them on their cell phones.

These technology-related techniques confirm the results of the VLS mentioned above, showing the participants' tendency to count on multimedia devices as important vocabulary-related aids.

Participants' suggestions relating to any control of their own learning were categorised as metacognitive strategies. Within this category, the use of multimedia devices was also dominant in participants' answers. Indeed, many reported using English learning applications on their cell phones, watching movies with subtitles, translating favourite songs, or listening to audio books as techniques to control and be proactive in their vocabulary learning process. Giving the obvious common use of cell phones and computers among many young adults nowadays, some participants also reported keeping their computers or phones in English, possibly to provide another source of vocabulary input in Algeria in which most of these devices are usually set in French or Arabic. These answers confirm again the strong reliance on multimedia devices that was mentioned earlier, as these strategies were among the most frequently used (in the top-10) among the participants of all four proficiency levels of the present study.

Table 2. Vocabulary learning strategies added by the participants

\begin{tabular}{|c|c|}
\hline Strategy Category & Participants Examples \\
\hline Determination & $\begin{array}{l}\text { - Use dictionary on cell phone } \\
\text { - Search for new words' meaning on Google } \\
\text { - Search meaning of words heard in movies and videos or read in books } \\
\text { - Make a list and record new words on the cell phone } \\
\text { - Read a novel, make a list of unknown words then translate them }\end{array}$ \\
\hline Memory & $\begin{array}{l}\text { - Remember English words which have a near meaning or form to } \\
\text { French } \\
\text { - Remember new words of the day just before going to sleep } \\
\text { - } 3 \text { or } 4 \text { hours after learning a new word, try to remember it to check if } \\
\text { it is memorized or not. } \\
\text { - Remember where and when the word was said } \\
\text { - Talk to mirror aloud/ utter the words aloud } \\
\text { - Use a visual dictionary with pictures } \\
\text { - Try to link the word to a topic and practice it orally aloud }\end{array}$ \\
\hline Cognitive & $\begin{array}{l}\text { - Write the new word many times on paper } \\
\text { - Write the new word on the hand } \\
\text { - Repeat the new word } \\
\text { - Learn by heart }\end{array}$ \\
\hline Metacognitive & $\begin{array}{l}\text { - Search translation of favourite songs } \\
\text { - Keep the computer and the cell phone in English } \\
\text { - Write about personal feelings } \\
\text { - Use English learning applications on the cell phone } \\
\text { - Watch movies with subtitles } \\
\text { - Listen to audio books while doing domestic activities or driving }\end{array}$ \\
\hline
\end{tabular}


When analysing the correlation between the use of strategies and the growth of vocabulary size, it was not significant for the majority of participants. However, an exception was found for some metacognitive strategies which emerged as having a high correlation and thus explaining significantly the growth of vocabulary size of the low-intermediate participants. Indeed, the strategies involving the use of internet to search for information or to communicate with others using English seemed to have a significant impact on the vocabulary size growth of the participants who had just joined the university. These results corroborate the findings mentioned above demonstrating that these two strategies were among the most frequently used consolidation strategies, along with other multimedia-related devices.

Even though multimedia-related strategies were frequently used by most participants, they were conducive to better vocabulary growth only for the low-intermediate students. An important aspect to mention is the fact that this group consisted of students who had just joined the university from high school and were tested at the beginning of the academic year- before any university instruction had taken place - and therefore this strong correlation mentioned above could not have been influenced by the English degree instruction but rather by other external factors such as the instruction they received in high school, or their motivation in learning English in and outside the classroom. One possible explanation might be that these freshers come from high school where English is only a school subject of their mainstream education; thus they feel the necessity to cope with lack of exposure to the TL—and therefore lack of vocabulary knowledge - through the use of multimedia as source of input to fill these gaps. At university, English becomes both the main subject of study and the language of instruction - except for some humanities courses such as Sociology or Philosophy which are done in Arabic. Therefore, students are exposed to English input which is much richer and more diversified. Their high motivation to study English might have acted as a driving force to enlarge their vocabulary through a variety of sources of input, granted that learners' motivation plays a crucial role in achieving success in language learning [17] [18].

In a foreign language environment like Algeria where English is used almost exclusively inside the classroom, university students - who are studying English with the purpose of getting an English language-related profession - might feel frustrated because of the lack of target language input. Besides the use of internet and TV, many subjects also mentioned the use of smartphones in order to practice English. Without ignoring the possible negative influence that using smartphones can have on vocabulary habits, one cannot ignore the potential positive impact of using phone applications to reinforce lexical knowledge as well as other varied technology-based resources including multimedia platforms. Thus, the use of multimedia devices such as internet, English speaking TV channels, or smartphone applications as a source of authentic input can be a way for EFL students to compensate for the limited exposure they get in the classroom; this can also demonstrate their high degree of autonomous learning of EFL vocabulary.

The strong reliance on multimedia related strategies of these Algerian participants is in line with the findings of other studies undertaken with Arabic speaking EFL learners for whom strategies such as watching English speaking media and technological 
devices are quite popular and used as an important source for vocabulary learning [19] [20] [21] [22] [23].

The psychological aspect of learning and more particularly strategy use and depth of learning is an element that needs to be taken into account when referring to vocabulary retention as the learner's degree of involvement and self-regulation while processing vocabulary leads to better retention of these words [24]. As a matter of fact, achieving self-regulation implies motivational, metacognitive, and behavioural involvement of the learner in his own learning process, by adapting the appropriate methods, strategies and tools that best fit his learning objectives in various contexts, and by self- monitoring his own performance to evaluate his progress. Learners succeeding in such self-regulation would have a greater flexibility and reactivity to their possible lack of vocabulary knowledge, and would therefore use strategies to resolve the issue [24].

\section{Conclusion}

The fact that most participants of the present study reported using technological devices as a way of improving their understanding and consolidation of vocabulary might be an indicator of another source of input worth exploiting as having a role in the growth of their overall vocabulary size. It seems therefore quite useful to encourage students at different proficiency levels to use such multimedia devices outside the classroom to improve their vocabulary knowledge. However, despite the fact that most students declared using technology-based resources during their language learning, only a limited group seemed to be able to make use of these metacognitive strategies to concretely enlarge the vocabulary size and develop lexical knowledge. There is therefore a need to assist EFL learners in their vocabulary learning by showing them, through strategy training, how to use technology related resources in the best way to serve their language learning in general and vocabulary growth in particular.

These finding have interesting implications for the classroom as teachers might consider giving more assignments involving the use of external sources of information such as movies, TV shows, radio programs, and social media platforms. As present-day students are extremely attracted and motivated by technological devices as well as multimedia and social networks, finding ways to use these 2.0 tools that the 21 st century technologies afford us is worth considering. If supervised by the teacher and used with the purpose of learning, such digital tools can be very beneficial in diversifying and developing the vocabulary knowledge of EFL students.

\section{Acknowledgment}

The $\mathrm{PhD}$ work from which the present paper is extracted has been conducted under the supervision of Professor Faiza Bensemmane from the University of Algiers 2 (Algeria). 


\section{$7 \quad$ References}

[1] Mayer, R. E. (2005). Cognitive theory of multimedia learning. In Mayer, R.E. (Ed.), The Cambridge handbook of multimedia learning. pp. 31-48. New York: CUP. https://doi. org/10.1017/CBO9780511816819.004

[2] Schmitt, N. (1997a). Vocabulary learning strategies. In N. Schmitt \& M. McCarthy (Eds.), Vocabulary: Description, acquisition and pedagogy. pp. 199-227. Cambridge: CUP.

[3] Bensemmane, F., \& Boukhedimi, Y. (2017). Intercultural dialogue and globalisation in the Euro-mediterranean area: what is the role of English? Revue LAROS-Université d'Oran: Conceptions, analyses et interculturalité. 14/15: 184-196.

[4] Oxford, R. L. (2013). Teaching and researching: Language learning strategies. New York: Routledge. https://doi.org/10.4324/9781315838816

[5] Ahmed, M. (1989). Vocabulary learning strategies. In P. Meara (Ed.), British studies in Applied Linguistics, Vol. 4. Beyond words. pp. 3-14. London: British Association of Applied Linguistics/Center for Language Teaching.

[6] Sanaoui, R. (1995). Adult learners' approaches to learning vocabulary in second languages. The Modern Language Journal. 79(1): 15-28. https://doi.org/10.1111/j.1540-4781.1995. tb05410.x

[7] Oxford, R. L. (2011). Strategies for learning a second or foreign language. Language Teaching. 44(2): 167-180. https://doi.org/10.1017/S0261444810000492

[8] Yangas, I. (2009). Multimedia Glosses and their effect on L2 text comprehension and vocabulary learning. Language Learning \& Technology. 13(2): 48-67. https://scholarspace. manoa.hawaii.edu/bitstream/10125/44180/1/13 02 yanguas.pdf

[9] Puspa, V. M. (2018). Relationships of using social media online to learning English at the English program. Humanoria. 9(1): 89-104. https://doi.org/10.21512/humaniora.v9i1.4169

[10] Alqunayeer, H. S. (2016). The impact of teaching through Twitter on students' vocabulary learning: A case study of Qassim University. World Journal of English Language. 6(2): 35. http://www.sciedupress.com/journal/index.php/wjel/article/view/9808; https://doi.org/ $10.5430 /$ wjel.v6n2p35

[11] Kabooha, R., \& Elyas, T. (2018). The effects of YouTube in multimedia instruction for vocabulary learning: perceptions of EFL students and teachers. English Language Teaching. 11(2). http://www.ccsenet.org/journal/index.php/elt/article/view/72929; https://doi. org/10.5539/elt.v11n2p 72

[12] Kabilan, M., \& Zahar, T. (2016). Enhancing students' vocabulary knowledge using the Facebook environment. Indonesian Journal of Applied Linguistics. 5(2): 217. https://ejournal. upi.edu/index.php/IJAL/article/view/1346; https://doi.org/10.17509/ijal.v5i2.1346

[13] Al-Tamimi, M. F., Al-Khawaldeh, A. H., Natsheh, H. I. M. A., \& Harazneh, A. A. (2018). The effect of using Facebook on improving English language writing skills and vocabulary enrichment among University of Jordan sophomore students. Journal of Social Sciences (COES\&RJ-JSS). 7: 187-214. http://centreofexcellence.net/index.php/JSS/article/view/ jss.2018.7.3.187.214; https://doi.org/10.25255/jss.2018.7.3.187.214

[14] Nikbakht, E., \& Boshrabadi, A. (2015). Analysing the potential of social networking sites on EFL learners' vocabulary mastery: A situated-learning approach. Theory and Practice in Language Studies. 5(8). http://www.academypublication.com/issues2/tpls/vol05/08/13.pdf; https://doi.org/10.17507/tpls.0508.13

[15] Nation, P. (1990). Teaching and learning vocabulary. Boston, MA: Heinle \& Heinle.

[16] Nation, P. (2012). The Vocabulary Size Test. https://www.wgtn.ac.nz/lals/resources/paul-nations-resources/vocabulary-tests/the-vocabulary-size-test/Vocabulary-Size-Test-information-and-specifications.pdf 
[17] Ur, P. (2002). A Course in language teaching: Practice and Theory. UK: CUP

[18] Şener, S. (2015). Vocabulary learning strategy preferences and vocabulary size of preservice English teachers. International Journal of Educational Researchers. 6(3): 15-30.

[19] Hamzah, S. G., Kafipour, R., \& Abdullah, S. K. (2009). Vocabulary learning strategies of Iranian undergraduate EFL students and its relation to their vocabulary size. European Journal of Social Sciences. 11(1): 39-50.

[20] Alahmadi A., \& Foltz A. (2020) Exploring the effect of lexical inferencing and dictionary consultation on undergraduate EFL students' vocabulary acquisition. PLoS ONE. 15(7). https://journals.plos.org/plosone/article?id=10.1371/journal.pone.0236798; https://doi.org/ 10.1371/journal.pone.0236798

[21] Mahmoud, A. M. A., \& Yalcin Arslan, F. (2017). The relationship between Iraqi EFL learners' vocabulary learning strategies use and their receptive vocabulary size. Arab World English Journal (AWEJ). 8(4): 303-317. https://doi.org/10.24093/awej/vol8no4.21

[22] Fageeh, A. (2013). Effects of MALL applications on vocabulary acquisition and motivation. Arab World English Journal. 4(4), 420-447. https://awej.org/images/AllIssues/Volume4/ Volume4Number4Dec2013/25.pdf

[23] Nirattisai, S. (2014). The different contribution of vocabulary learning strategies to students with varying vocabulary size. Journal of Studies in Education. 4(4): 94. http://www.macrothink.org/journal/index.php/jse/article/view/6196; https://doi.org/10.5296/jse.v4i4.6196

[24] Zimmerman, B. J. (1998). Academic studding and the development of personal skill: A selfregulatory perspective. Educational psychologist. 33(2-3): 73-86. https://doi.org/10.1080/0 $\underline{0461520.1998 .9653292}$

[25] Ouadoud, M., et al. (2021). Overview of E-learning platforms for teaching and learning. International Journal of Recent Contributions from Engineering, Science \& IT (iJES). 9(1): 50-70. https://doi.org/10.3991/ijes.v9i1.21111

[26] Noprisson, H. (2020). A survey of the online learning implementation during COVID-19 outbreak. International Journal of Recent Contributions from Engineering, Science \& IT (iJES). 8(4): 18-27. https://doi.org/10.3991/ijes.v8i4.17913

[27] Prayogi, S. (2020). The effectiveness of eLearning usage in classroom teaching to promote critical thinking ability. International Journal of Recent Contributions from Engineering, Science \& IT (iJES). 8(4): 61-68. https://doi.org/10.3991/ijes.v8i4.18023

\section{Author}

Mrs Adela Talbi Hassani is an Assistant lecturer since 2010 and a $\mathrm{PhD}$ researcher at the English Department of the University of Algiers 2 (Algeria). She has just completed a $\mathrm{PhD}$ thesis in Applied Linguistics and Didactics (unpublished yet) entitled "English Vocabulary Size Growth and Vocabulary Learning Strategies: A Comparative Study across the Three English Degree Years at the University of Algiers 2". She can be contacted by email at: adelaia@yahoo.fr

Article submitted 2021-06-11. Resubmitted 2021-07-08. Final acceptance 2021-07-13. Final version published as submitted by the authors. 